\title{
The phylogeny of desmostylians revisited: proposal of new clades based on robust phylogenetic hypotheses
}

\author{
Kumiko Matsui ${ }^{\text {Corresp., 1, } 2 \text {, Takanobu Tsuihiji }}{ }^{3,4}$ \\ ${ }^{1}$ The Kyushu University Museum, Kyushu University, Fukuoka, Japan \\ 2 The University Museum, The University of Tokyo, The University of Tokyo, Tokyo, Japan \\ 3 Department of Earth and Planetary Science, Graduate school of Science, The University of Tokyo, Tokyo, Japan \\ 4 Department of Geology and Paleontology, National Museum of Nature and Science, Tsukuba, Japan \\ Corresponding Author: Kumiko Matsui \\ Email address: kumiko_matsui@me.com
}

Background- Desmostylia is a clade of extinct aquatic mammals with no living members. Today, this clade is considered belonging to either Afrotheria or Perissodactyla. In the currently-accepted taxonomic scheme, Desmostylia includes two families, 10 to 12 genera, and 13 -14 species. There have been relatively few phylogenetic analyses published on desmostylian interrelationship compared to other vertebrate taxa, and two main, alternative phylogenetic hypotheses have been proposed in previous studies. One major problem with those previous studies is that the numbers of characters and OTUs were small.

Methods- In this study, we analyzed the phylogenetic interrelationship of Desmostylia based on a new data matrix that includes larger numbers of characters and taxa than in any previous studies. The new data matrix was compiled mainly based on data matrices of previous studies and included 3 outgroups and 13 desmostylian ingroup taxa. Analyses were carried out using 5 kinds of parsimonious methods.

Results- Strict consensus trees of the most parsimonious topologies obtained in all analyses supported the monophyly of Desmostylidae and paraphyly of traditional Paleoparadoxiidae. Based on these results, we propose phylogenetic definitions of the clades Desmostylidae and Paleoparadoxiidae based on common ancestry. 


\section{$1 \quad$ The phylogeny of desmostylians revisited: proposal}

\section{2 of new clades based on robust phylogenetic}

\section{3 hypotheses}

5 Kumiko Matsui ${ }^{1,2}$, Takanobu Tsuihiji ${ }^{3,4}$

6

$7{ }^{1}$ The Kyushu University Museum, Kyushu University, Fukuoka, Fukuoka, Japan

82 The University Museum, The University of Tokyo, The University of Tokyo, Tokyo, Japan

$9{ }^{3}$ Department of Earth and Planetary Science, Graduate school of Science, The University of

10 Tokyo, Bunkyo, Tokyo, Japan

$11{ }^{4}$ present address: Department of Geology and Paleontology, National Museum of Nature and

12 Science, Tsukuba, Ibaraki, Japan

14 Corresponding Author:

15 Kumiko Matsui ${ }^{1,2}$

16 Kyushu University Museum, 6-10-1 Hakozaki, Higashi, Fukuoka, 812-8581, Japan

17 Email address: kumiko_matsui@me.com 


\section{Abstract}

21 Background-Desmostylia is a clade of extinct aquatic mammals with no living members.

22 Today, this clade is considered belonging to either Afrotheria or Perissodactyla. In the currently-

23 accepted taxonomic scheme, Desmostylia includes two families, 10 to 12 genera, and $13-14$

24 species. There have been relatively few phylogenetic analyses published on desmostylian

25 interrelationship compared to other vertebrate taxa, and two main, alternative phylogenetic

26 hypotheses have been proposed in previous studies. One major problem with those previous

27 studies is that the numbers of characters and OTUs were small.

29 Methods - In this study, we analyzed the phylogenetic interrelationship of Desmostylia based on

30 a new data matrix that includes larger numbers of characters and taxa than in any previous

31 studies. The new data matrix was compiled mainly based on data matrices of previous studies

32 and included 3 outgroups and 13 desmostylian ingroup taxa. Analyses were carried out using 5

33 kinds of parsimonious methods.

35 Results- Strict consensus trees of the most parsimonious topologies obtained in all analyses

36 supported the monophyly of Desmostylidae and paraphyly of traditional Paleoparadoxiidae.

37 Based on these results, we propose phylogenetic definitions of the clades Desmostylidae and

38 Paleoparadoxiidae based on common ancestry. 
40

41

42

43

\section{Introduction}

Desmostylia is a clade of extinct aquatic mammals with no living members (Repenning, 1965; Inuzuka, 1984a; Inuzuka, 2000a; Inuzuka, 2000b; Domning, 2002; Gingerich, 2005). The phylogenetic affinities of the clade among mammals are still debated, having been hypothesized as belonging to Afrotheria (Domning, Ray and McKenna, 1986), Perissodactyla (Cooper et al., 2014; Rose et al., 2015) or Paenungulatomorpha (Gheerbrant, Filippo, and Schmitt, 2016), due to their specialized morphology (Figure 1).

In the currently-accepted taxonomic scheme, Desmostylia includes two families, 10 to 12 genera, and 13-14 species (Shikama, 1966; Kohno, 2000; Inuzuka, 2005; Domning and Barnes, 2007; Barnes, 2013; Beatty and Cockburn, 2015; Chiba et al., 2016). The two families are Desmostylidae Osborn, 1905, and Paleoparadoxiidae Reinhart, 1959. Presently, Desmostylidae includes Ashoroa laticosta, Cornwallius sookensis, Ounalashkastylus tomidai, Kronokotherium brevimaxillare, Desmostylus japonicus, D. hesperus and D. (Vanderhoofius) coalingensis (Domning and Barnes, 2007; Inuzuka, 2005; Chiba et al., 2016). Paleoparadoxiidae has been considered to include two subfamilies, Behemotopsinae including Seuku emlongi, Behemotops proteus and Behemotops katsuiei (Domning, Ray and McKenna, 1986; Inuzuka, 2000a; Beatty and Cockburn, 2015) and Paleoparadoxiinae that includes Archaeoparadoxia weltoni, Paleoparadoxia tabatai, Neoparadoxia repenningi and Neoparadoxia cecilialina (Barnes, 2013). It is noteworthy, however, that results of some phylogenetic analyses do not support this taxonomic scheme (e.g. Beatty and Cockburn, 2015).

\section{Previous studies on desmostylian phylogenetic interrelationships}


There have been relatively few phylogenetic analyses published on desmostylian

64

65

66

67

68

69 interrelationships compared to other vertebrate taxa. The results of previous studies are summarized here (Figure 2). Domning, Ray and McKenna (1986) performed the first phylogenetic analysis that included Desmostylia. Before their study, Osborn (1905) and Reinhart (1953) suggested that Desmostylia is closely related to Sirenia and Proboscidea, and this hypothesis had been widely accepted. However, it had not been demonstrated to which of these two clades Desmostylia is more closely related. Domning, Ray and McKenna (1986) analyzed phylogenetic relationships among Prorastomus, Protosiren, crown Sirenia, the primitive tethytherian Minchenella, Anthracobune, Moeritherium, Barytherium, Prodeinotherium, Deinotherium, Paleomastodon, crown Proboscidea and Desmostylia including Behemotops proteus, B. emlongi, Paleoparadoxia, Cornwallius and Desmostylus. As a result, Desmostylia was found to be most closely related to Proboscidea. In addition, Domning, Ray and McKenna (1986) proposed the hypothesis that Minchenella was a suitable candidate for the ancestor (or the sister taxon) of the clade consisting of Desmostylia and Proboscidea, suggesting the origin of the latter two clades in Asia.

8 Clark (1991) performed the first phylogenetic analysis of desmostylian interrelationships including the new species of Paleoparadoxia that he described. His analysis included Behemotops emlongi, B. proteus, Cornwallius, Desmostylus, Paleoparadoxia tabatai, P. weltoni and two undescribed desmostylian specimens as OTUs. The result corroborated the monophyly of Paleoparadoxia and strongly supported a clade consisting of Desmostylus, Cornwallius and Paleoparadoxia. However, the relationship between Paleoparadoxia and the clade including Desmostylus and Cornwallius was unresolved. 
86 all valid desmostylian species including new primitive desmostylid materials described in

87 Inuzuka (2000a). His data matrix includes more post-cranial characters than were used in

88 previous phylogenetic analyses of desmostylians. However, the methods employed for these

89 phylogenetic analyses were not described in either paper. According to Inuzuka's results,

90 Desmostylia consists of two clades, Desmostylidae (A. laticosta, C. sookensis, K. brevimaxillare,

91 D. hesperus, D. japonicus and D. coalingensis) and Paleoparadoxiidae (B. proteus, B. katsuiei, $P$.

92 weltoni, "P. media" and "P. tabatai").

93 Beatty (2009) assembled a new matrix based on previous studies and included new data on Cornwallis sookensis. He used Moeritherium and Pezosiren portelli as outgroups of

Desmostylia and included nearly all species of Desmostylia. The tree that Beatty (2009) obtained is different in topology from the one in Inuzuka (2000a and 2005) in that Behemotops spp. were

97 placed below the node containing other traditional paleoparadoxiids, making the traditionallyrecognized family Paleoparadoxiidae paraphyletic.

Barnes (2013) made a new data matrix for analyzing the phylogenetic position of a new

100 paleoparadoxiid as well as the interrelationships of Paleoparadoxiidae. His data matrix includes

101 numerous post-cranial skeletal characters. In the cladogram that he obtained, three formerly-

102 known species of Paleoparadoxia (separated into three genera by Barnes, 2013) formed the

103 clade Paleoparadoxiinae. The problem with his analysis, however, is that it was based on the

104 assumption of the traditional Paleoparadoxiidae including Behemotops being monophyletic. This

105 assumption was not rigorously tested and had been challenged by Beatty (2009).

106 A more recent analysis by Chiba et al. (2016) was based on a data matrix modified from

107 Beatty (2009). Chiba et al. (2016) added two molar characters to Beatty (2009)'s matrix and 
108 analyzed the phylogenetic position of Ounalashkastylus. The resulting tree has a topology

109 similar to the one obtained in Beatty (2009), with Ounalashkastylus placed between Cornwallius

110 and the clade consisting of Desmostylus and Vanderhoofius spp.

111

112 Purpose of this study

113 The above review of past phylogenetic analyses points to problems with these studies. Firstly,

114 not all valid desmostylian species were included in most previous analyses. Secondly, almost all

115 analyses were based on the assumption that Desmostylia is a member of Afrotheria. Recently,

116 however, this assumption was challenged based on phylogenetic analyses indicating that

117 Desmostylia is a part of Perissodactyla (Cooper et al., 2014; Rose et al., 2015) or

118 Paenungulatomorpha (Gheerbrant, Filippo, and Schmitt, 2016). If this is the case, using

119 afrotherians (e.g., proboscideans and/or sirenians) as outgroups for a phylogenetic analysis of

120 desmostylian interrelationships is problematic. It is therefore necessary to run phylogenetic

121 analyses using alternative outgroups representing different hypotheses of affinities of

122 Desmostylia to examine effects of outgroup selections. Thirdly, for the numbers of taxa being

123 analyzed, relatively few characters were used in past analyses. To summarize, global phylogeny

124 of Desmostylia still needs to be analyzed by (1) incorporating all currently-accepted species, (2)

125 using several outgroups reflecting various hypotheses of desmostyian affinities and (3)

126 producing a data matrix with more characters.

127 In order to rectify these three problems, a new, largest data matrix for desmostylian

128 interrelationships was assembled in this study and was analyzed using different outgroups

129 reflecting currently-proposed hypotheses of desmostylian affinities. The resulting trees were then 
130 used to obtain a robust topology independent of outgroups in order to propose new phylogenetic

131 definitions of the clades Desmostylidae and Paleoparadoxiidae. 


\section{Materials \& Methods}

135 Taxon Sampling

136 1. Outgroups

137 In this study, three separate analyses were performed using different outgroups to account for

138 uncertainty of desmostylian affinities with other mammals. Desmostylia has been hypothesized

139 as belonging to Afrotheria, Perissodactyla or Paenungulatomorpha. In the case of the Afrotherian

140 hypothesis, it is also not certain whether Desmostylia is closer to Sirenia or Proboscidea. Herein

141 the following three analyses using different sets of outgroups were conducted. These analyses

142 cover all appropriate outgroups suggested by the three phylogenetic hypotheses above.

143 (1) Analysis 1. Anthracobune spp. as the outgroup (coding based on Cooper et al. (2014)),

144 (2) Analysis 2. Pezosiren portelli, a primitive sirenian, and Moeritherium spp., a primitive

145 proboscidean, as the outgroups (coding based on NMNS PV-20726, 20970-4, Andrews (1904

146 and 1906), Holroyd et al. (1996), and Delmer et al. (2006)),

147 (3) Analysis 3. Anthracobune spp., Pezosiren portelli and Moeritherium spp. as the

148 outgroups.

149

150 2. In-group taxa

151 In this study, 13 species of desmostylians were included as OTUs. All presently-accepted

152 desmostylian species were included. A possible exception is Kronokotherium brevimaxillare

153 which has been considered a junior synonym of Desmostylus hesperus (Domning, 1996) and is 
154 known only from highly fragmentary specimens (Pronina, 1957; Beatty, 2009). The following is

155 the list of OTUs with sources for coding.

156 1. Behemotops proteus (based on USNM 244035; Domning, Ray and McKenna, 1986;

157 Beatty and Cockburn, 2015; Ray, Domning and McKenna, 1994)

158 2. Behemotops katsuiei (based on AMP 22; Inuzuka, 2000a; Inuzuka, 2009)

159 3. Seuku emlongi (based on USNM 244033 and 186889; Domning, Ray, and McKenna,

160 1986; Beatty and Cockburn, 2015; Ray, Domning, McKenna, 1994)

161 4. Archaeoparadoxia weltoni (based on UCMP 114285; Clark, 1991)

162 5. Paleoparadoxia tabatai (based on NMNS PV-5601; Shikama, 1966; Ijiri and Kamei, $1631961)$

164 6. Neoparadoxia repenningi (based on UCMP

165 81302; Inuzuka, 2005)

$1667 . \quad$ Neoparadoxia cecilialina (based on LACM 150150; Barnes, 2013)

167 8. Ashoroa laticosta (based on AMP 21; Inuzuka, 2000a; Inuzuka, 2011)

$1689 . \quad$ Cornwallius sookensis (based on USNM 11073, 11075, 181738, 181740, 181741, and

169 214740; Beatty, 2006 and 2009)

170 10. Ounalashkastylus tomidai (based on Chiba et al., 2016; Jacobs et al., 2007; Jacobs et al., 171 2009)

172 11. Desmostylus japonicus (based on NMNS PV-5600; GSJ-F02071; Kohno, 2000;

173 Yoshiwara and Iwasaki, 1902)

174 12. Desmostylus hesperus (based on UHR-18466; GSJ-F7743; UCMP 32742; Ijiri and

175 Kamei, 1961; Inuzuka, 1980a, 1980b, 1981a, 1981b, 1982, 1988, and 2009) 
176 13. Desmostylus (Vanderhoofius) coalingensis (based on USNM 244489; UCMP 39990;

177 Reinhart, 1959; Inuzuka, 2005; Beatty, 2009)

178

179 Software and Analysis

180 The data matrix was assembled in Mesquite v 3.6 (Maddison and Maddison, 2011). Analyses

181 were conducted with equally weighted parsimony with PAUP* (Swofford, 2003) version 4.0a,

182 build 165 for Macintosh using the heuristic search algorithm with Tree Bisection Reconnection

183 (TBR) branch swapping (saving 10 trees per replication). Branch support was estimated with

184 bootstrap resampling method (10,000 replicates). Phylogenetic trees were illustrated by using the

185 geoscalePhylo function in the strap package (Gradstein, Ogg, and Schmitz, 2012) for the

186 statistical programming language R (R Core Team, 2017). The divergence time estimation was

187 also calculated by geoscalePhylo function in trap package.

188

189 Characters and Data Matrices

190 Firstly, analyses were run based on previously-published character matrices (Inuzuka, 2000a;

191 Barnes, 2013; Chiba et al., 2016; Clark, 1991; Beatty, 2009) to verify the published tree

192 topologies. Secondly, those matrices were compiled, with coding revised and new characters

193 added. Overall, 110 morphological characters were employed in the new matrix (Figure 3).

194 Character descriptions and data matrices are provided in S1 File and Table S1. 
196 Results

197

198 Reproducibility of previous data matrices

199 Among previously-published data matrices, only the data matrix of Inuzuka (2005) did not

200 produce the original topology presented in the paper (Figure S1).

201

202 Analyses based on a new data matrix

203 All results are shown in Figure 4 and Figures S2-3, S5-6, and S8-9. Bootstrap consensus trees

204 obtained in all the analyses showed the identical topology (Figure 4; Figures S3, S6, S9) whereas

205 strict consensus trees (Figures S2, S5, S8) of these analyses had partly different topologies.

206 However, all these topologies (Figure 4, and S2-3, S5-6, S8-9) agree on both traditional

207 Paleoparadoxiinae including Archaeoparadoxia, Paleoparadoxia and Neoparadoxia and

208 traditional Desmostylidae including Ashoroa, Cornwallius, Ounalashkastylus and Desmostylus

209 being monophyletic as well as on Desmostylidae + Paleoparadoxiinae forming a clade. On the

210 other hand, Paleoparadoxiidae sensu Inuzuka (2000a, 2005) and Barnes (2013) that includes

211 Paleoparadoxia, Archaeoparadoxia, Neoparadoxia, Seuku and Behemotops spp. was not

212 recovered as a clade. The positions of Behemotops spp. and Seuku differs among the strict

213 consensus trees obtained in Analyses 1-3. In all the bootstrap consensus trees of these analyses,

214 Behemotops and Seuku formed an unresolved polytomy with the clade containing the remaining

215 desmostylians. These genera thus diverged before the split between Paleoparadoxiinae and

216 Desmostylidae.

PeerJ reviewing PDF | (2018:12:33598:1:1:NEW 3 Jul 2019) 


\section{Discussion}

219

220

221

222

223

224

225

226

227

228

229

230

231

232

233

234

235

236

237

238

239

240

\section{Reproducibility of data matrices}

The analysis based on Inuzuka's (2005) original data matrix produced a completely unresolved polytomy with no resolution. This matrix includes a relatively few characters for the number of OTUs, likely contributing to non-resolution of the tree topology.

\section{Characters supporting each clade in the present analyses}

Although not all character distribution patterns were shared among the strict consensus trees of Analyses 1 through 3 (Figures S4, 7, 10), many common synapomorphies were found for major clades. Such synapomorphies identified in all the strict consensus trees are described below.

The monophyly of traditional Desmostylidae consisting of Ashoroa, Cornwallius, Ounalashkastylus and Desmostylus was supported by the presence of 7 or more cusps on M3 (c. 29(1)), conical and tusk-like lower incisors (c. 32( 2)), no passage anterior to the external auditory meatus connecting to the skull roof (c. 37(1)), presence of an anterior orbital groove (c. 46(1)), having cancellous bones of vertebrae (centrum) (c. 75(3)) and shallow and wide shape of intertubercular groove in humeus(c. 93(2)). The monophyly of traditional Paleoparadoxiinae consisting of Archaeoparadoxia, Paleoparadoxia and Neoparadoxia was supported by the mandibular symphysis rotated anteroventrally (c. $68(1)), 14$ or 15 theoretic vertebrae (c. $78(1)$ ), and a flat femoral shaft (c. 103 (2)). The clade consisting of Paleoparadoxiinae + Desmostylidae was supported by the absence of the p3 paraconid (c. 12(1)), fused double roots of p3 and p4 (c. 14(2)), swollen and appressed molar cusps (c. 17(1)), enlarged P4-M3 hypoconulid and 
241 entoconid (c. 18(1)) and having osteosclerosis bones of vertebrae (centrum) (c. 75(1)).

242 Synapomorphies of Desmostylia are a tusk root enlarged in diameter (c. 5(1)), an enlarged lower

243 canine (c. 6(1)), the hypoconid and entoconid reduced in height in p4 talonid (c. 15(1)) a

244 transversely broad hypoconulid shelf of $\mathrm{m} 3$ (c. 16(1)), transversely aligned lower incisors (c.

$24530(1)$ ), a flattened or conical and tusk-like lower incisor (c. 32(1 \& 2)), absent of foramen within

246 squamosal passing anterior from external auditory meatus (c. 36(1)), elongating to much behind

247 alveolus of incisors and canine in posterior part of premaxilla (c. 38(1)), high and closed

248 ventrally external auditory meatus (c. 39(1)), elongated paraoccipital process (c. 40(1)), the

249 presence of the foramen post-zygomaticus (c. 41(1)), basioccipital bone's length less than half of

250 the width of the foramen magnum (c. 49(1)), paired sternebrae (c. 73(1)), exist of the ring like

251 shape epiphyseal line in centrum (c. 83(1)), shallow and narrow intertubercular groove in

252 humerus (c. 93(1)), distal surface inclined medially in capitate bone (c. 103(1)), and tibia is

253 medially twisted with its distal articular surface facing laterally (c. 106(1)). The monophyly of

254 Desmostylus (D. japonicus + D. hesperus + "Vanderhoofius" coalingensis) was supported by the

255 sigmoid upper margin of mandibular body (c. 64(1)). The monophyly of D. hesperus +

256 "Vanderhoofius" coalingensis was supported by the loss of the upper canine (c. 3(1)), the

257 presence of one pair of upper incisors (c. 33(1)), premaxilla contacting the frontal (c. 42(1)) and

258 the laterally convex interalveolar margin in the diastema of the mandible (c. 70(1)). The

259 monophyly of Neoparadoxia was supported by a small angle between the anterior and posterior

260 margins of the coronoid process (c. 65(1)), the tibia-fibula articulation enlarged and extended

261 proximally (c. 104(1)) and the astragalar facet on the tibia tilted at least 60 degrees from

262 horizontal (c. 105(1)). 
264 Comparisons with MPTs and synapomorphies for clades obtained in previous studies

265 In this study, a new data matrix was constructed including more characters and taxa

266 than those used in previous studies. The present MPT topologies are clearly different from the

267 one presented in Inuzuka (2000a, 2005) but are mostly consistent with the one in Beatty (2009).

268 An assumption by Barnes (2013) that both Paleoparadoxiinae and Paleoparadoxiidae were

269 monophyletic was rejected herein. In addition, the relationship among Archaeoparadoxia,

270 Paleoparadoxia and Desmostylidae was unresolved in Chiba et al. (2016) likely because their

271 matrix did not include enough characters. In this study, the data matrix consisting of more

272 characters successfully resolved the relationship among these three taxa.

273 The synapomorphies identified in the present study are somewhat different from those

274 proposed by previous studies. Clark (1991) identified 2 synapomorphies for traditional

275 Paleoparadoxiinae and 3 synapomorphies for Desmostylidae + Paleoparadoxiinae. However, the

276 present analyses did not find any of these characters diagnosing these clades except for Clark's

277 (1991) Character 29 (Character 68 in the present data matrix). As an OTU, Clark's (1991) matrix

278 included an undescribed specimen (USNM 23895) not included in the present analyses, possibly

279 causing differences in synapomorphies of these clades.

280 Inuzuka (2005), on the other hand, identified four synapomorphies for Desmostylia, 6 for

281 Desmostylidae, 3 for traditional Paleoparadoxiinae and 2 for Desmostylus. None of those

282 synapomorphies identified in Inuzuka (2005; his Characters 1, 3, 8, 12, 14, 15, 31, 32, 34 and 35)

283 supported these clades in the present analyses. The strict consensus topologies obtained in the

284 present analyses are different from the one presented in Inuzuka (2005). Therefore, such

285 differences may be expected. 
289 Taxonomy of Desmostylia

290

291 The present results suggest that the previously-proposed taxa Desmostylidae and

292 Paleoparadoxiinae are monophyletic and valid. On the other hand, Paleoparadoxiidae including

293 Behemotops (Inuzuka, 2001; Barnes, 2013; Inuzuka, 2009) turned out to be paraphyletic.

294 Therefore, the currently-used taxon Paleoparadoxiidae needs to be re-defined as a clade

295 excluding Behemotops, leaving it with the same taxonomic content as the currently-used

296 Paleoparadoxiinae (Beatty, 2009). Behemotops and Seuku are not included in either

297 monophyletic Desmostylidae or Paleoparadoxiidae. Additionally, Vanderhoofius

298 (="Desmostylus") coalingensis, D. hesperus and D. japonicus formed a clade in the strict

299 consensus trees of all present analyses. Therefore, these results support the hypothesis of Kohno

300 (2000) and Santos et al. (2016) that Vanderhoofius is a junior synonym of Desmostylus.

301

302 New Definition of Desmostylian Clades

303 In this study, the monophyly of traditional Paleoparadoxiidae was rejected. Desmostylian

304 families have been defined based on a traditional convention of simply enumerating included

305 taxa. Such an approach was regarded as non-evolutionary by de Queiroz and Gauthier (1990,

306 1992, and 1994). These authors instead proposed phylogenetic definitions of taxon names, i.e.,

307 defining taxon names in terms of common ancestry, which has resulted in the proposal of the

308 formal International Code of Phylogenetic Nomenclature (PhyloCode) governing the naming of

309 clades (Cantino and de Queiroz, 2010). Their rationale is followed here and traditional 
310 desmostylian family names are converted to clade names with new definitions following the

311 PhyloCode rules.

312

313 DESMOSTYLIDAE OSBORN 1905 (CONVERTED CLADE NAME)

314 Definition: Desmostylidae refers to the clade consisting of Desmostylus hesperus Marsh 1888

315 and all organisms or species that share a more recent common ancestor with $D$. hesperus than

316 with Paleoparadoxia tabatai Tokunaga 1939.

317 Comments: Because the Order Desmostylia is currently divided into two families, Desmostylidae

318 and Paleoparadoxiidae, it is appropriate to convert these taxa to branch- or stem-based clades so

319 that all desmostylian species except for a few, early-diverging forms (e.g., those regarded as

320 Family indeterminate by Beatty and Cockburn, 2015) are included in one of these clades. All

321 taxa traditionally regarded as constituting Desmostylidae formed a clade in the present analyses

322 (Figure 4). Therefore, the converted clade of Desmostylidae include the same set of currently

323 valid taxa as the traditional Family Desmostylidae.

324 Based on the current analyses, Desmostylidae is diagnosed by the following

325 characteristics: the presence of 7 or more cusps on M3 (c. 29(1)), conical and tusk-like lower

326 incisors (c. 32( 2)), no passage anterior to the external auditory meatus connecting to the skull

327 roof (c. 37(1)), presence of an anterior orbital groove (c. 46(1)), having cancellous bones of

328 vertebrae (centrum) (c. 75(3)) and shallow and wide shape of intertubercular groove in

329 humweus(c. 93(2)).

330

331 PALEOPARADOXIIDAE REINHART, 1959 (CONVERTED CLADE NAME) 
332 Definition: Paleoparadoxiidae refers to the clade consisting of Paleoparadoxia tabatai Tokunaga

3331939 and all organisms or species that share a more recent common ancestor with P. tabatai than

334 with Desmostylus hesperus Marsh 1888.

335 Comments: Traditionally-recognized paleoparadoxiids formed a paraphyletic group and thus did

336 not form a clade in all present analyses (Figure 4), necessitating a revision of the content of the

337 taxon. Based on the present analyses, the clade Paleoparadoxiidae is diagnosed by the following

338 synapomorphies: the mandibular symphysis rotated anteroventrally (c. 68(1)), 14 or 15 theoretic

339 vertebrae (c. 78(1)), and a flat femoral shaft (c. 103 (2)).

340

341 DESMOSTYLOIDEA Osborn, 1905 (CONVERTED CLADE NAME)

342 Definition: Desmostyloidea refers to the clade originating with the most recent common ancestor

343 of Desmostylus hesperus Marsh 1888 and Paleoparadoxia tabatai Tokunaga 1939.

344 Comments: The new clade Desmostyloidea includes Desmostylidae and Paleoparadoxiidae as its

345 subclades. Because these two clades are defined above as branch-based clades, any member of

346 Desmostyloidea belongs to either Desmostylidae or Paleoparadoxiidae.

347 The following synapomorphies of Desmostyloidea were identified in the present

348 analyses: The clade consisting of Paleoparadoxiinae + Desmostylidae was supported by the

349 absence of the p3 paraconid (c. 12(1)), fused double roots of p3 and p4 (c. 14(2)), swollen and

350 appressed molar cusps (c. 17(1)), enlarged P4-M3 hypoconulid and entoconid (c. 18(1)) and

351 having osteosclerosis bones of vertebrae (centrum) (c. 75(1)).

352

353

DESMOSTYLIA REINHART, 1953 (CONVERTED CLADE NAME)

PeerJ reviewing PDF | (2018:12:33598:1:1:NEW 3 Jul 2019) 
354 Definition: Desmostylia refers to the clade originating with the first organism or species to

355 possess as an apomorphy the transversely broad hypoconulid shelf of the third molar, as

356 inherited by Desmostylus hesperus Marsh 1888.

357 Comments: The order Desmostylia was established by Reinhart (1953) for the genera

358 Desmostylus and Cornwallius. Since then, several new genera have been referred to this order by

359 Reinhart (1959), Domning, Ray and McKenna (1986), Inuzuka (2000), Barnes (2013), Beatty

360 and Cockburn (2015) and Chiba et al. (2016). In the present analyses, such genera were all found

361 to be included in one clade and share numerous synapomorphies.

362 Several alternative phylogenetic definitions of Desmostylia are possible, but the newly

363 defined clade should approximate traditional use of the name. The node-based definition would

364 be "the clade originating with the most recent common ancestor of Desmostylus hesperus Marsh

365 1888, Paleoparadoxia tabatai Tokunaga 1939, Seuku emlongi (Domning, Ray and McKenna

366 1986), Behemotops proteus (Domning, Ray and McKenna 1986) and Behemotops katsuiei

367 Inuzuka, 2000.” This definition, however, would exclude from the clade earlier-diverging or

368 "stem" species on this lineage. The branch-based definition, on the other hand, would be "the

369 clade consisting of Desmostylus hesperus Marsh 1888 and all organisms or species that share a

370 more recent common ancestor with D. hesperus than with Anthracobune pinfoldi Pilgrim 1940,

371 Trichechus manatus Linnaeus 1758, or Elephas maximus Linnaeus 1758", considering currently

372 hypothesized sister clades of Desmostylia. However, the exact relationships of Desmostylia with

373 other mammalian clades are still debated and it is possible that other clades will turn out to be

374 more closely related to Desmostylia than those that have been hypothesized. Considering that

375 such a case would result in a wildly different taxonomic content of Desmostylia than that

376 currently recognized, this branch-based definition also appears inappropriate. 
378 Desmostylidae and Hay’s (1923) Desmostyliformes. It included currently-recognized

379 Paleparadoxia, Cornwallius, and Desmostylus. Although various recent studies identified

380 diagnostic features of Desmostylia (e.g. Inuzuka, 2005; Matsui, 2017; Matsui et al. 2018), they

381 did not attempt define the name of the clade Desmostylia. In this study we newly established the

382 apomorphy-based definition for this clade. The clade defined in this way includes not only the

383 derived clades Paleoparadoxiidae and Desmostylidae that share the "bundled, pillar-like" teeth,

384 but also earlier-diverging members Seuku and Behemotops possessing a transversely broad

385 hypoconulid shelf that would have been a precursor of the highly specialized dental morphology

386 of those clades. Considering that members of Desmostylia have been recognized based on such

387 unique dental morphology present in derived species, it is most reasonable to adopt the

388 apomorphy-based definition based on a dental characteristic as proposed here. 


\section{Conclusions}

391 In this study, a new data matrix was assembled for analyzing phylogenetic interrelationships of

392 Desmostylia. The results of the analyses support a monophyletic Paleoparadoxiinae consisting of

393 Archaeoparadoxia, Paleoparadoxia and Neoparadoxia as well as a Desmostylidae consisting of

394 Ashoroa, Cornwallius, Ounalashkastylus, and Desmostylus. In addition, Behemotops and Seuku

395 turned out to form an unresolved polytomy with the clade of Paleoparadoxiinae +

396 Desmostylidae. Based on these results, the phylogenetic definitions of Desmostylia,

397 Desmostylidae and Paleoparadoxiidae, as well as a new clade Desmostyloidea, are proposed. 


\section{Institutional abbreviations}

399 AMP: Ashoro Museum of Paleontology, Hokkaido, Japan; GSJ: Geological Survey of Japan,

400 Ibaraki, Japan; LACM: Natural History Museum of Los Angeles County, Los Angeles,

401 California, USA; NMNS: National Museum of Nature and Science, Tokyo, Japan; UCMP:

402 University of California Museum of Paleontology, Berkeley, California, USA; UHR: Hokkaido

403 University Museum, Sapporo, Japan; USNM: Department of Paleobiology, U.S. National

404 Museum of Natural History, Smithsonian Institution, Washington, D.C., USA. 


\section{Acknowledgements}

407 Thanks are due to Nicholas Pyenson, David Bohaska (USNM), Mark Goodwin, and Patricia

408 Holroyd (UCMP), Jorge Velez-Juarbe, Samuel A. McLeod, and Vanessa R. Rhue (LACM),

409 Naoki Kohno (NMNS), and C. H. Tsai (NMNS, currently National Taiwan University), Hiroshi

410 Sawamura, Tatsuro Ando, and Tatsuya Shinmura (AMP), Yoshitsugu Kobayashi, Tomonori

411 Tanaka, Tsogtbaatar Chinzorig, Kota Kubo (UHM) for allowing us to study desmostylian

412 specimens under their care. KM also thanks Kazuyoshi Endo, Takenori Sasaki, Makoto Manabe,

413 and Naoki Kohno for helpful discussions on her Ph.D. dissertation including a chapter on which

414 this paper is based. We are grateful for the constructive reviews by the editor, John Hutchinson,

415 and reviewers, Brian L. Beatty and Daryl P. Domning. Financial support was provided by JSPS

416 Research Grant (JSPS 16J00546) and Sasakawa Scientific Research Grant 2018-6028 from the

417 Japan Science Society to KM. 


\section{References}

420 Andrews, C. W. A descriptive catalogue of the Tertiary Vertebrata of the Fayum, Egypt, based on the collection of the Egyptian Government in the Geological Museum, Cairo, and on the collection in the British Museum (Natural History). Trustees of the British Museum (Natural History), London; 1906.

Andrews, C. W. III. Further notes on the Mammals of the Eocene of Egypt. Geological Magazine (Decade V). 1904; 1: 109-115.

Barnes, L. G. A new genus and species of Late Miocene paleoparadoxiid (Mammalia,

Beatty, B. L. and Cockburn T. C. New insights on the most primitive desmostylian from a partial Desmostylia) from California. Contributions in Science. 2013; 521: 51-114. skeleton of Behemotops (Desmostylia, Mammalia) from Vancouver Island, British

Beatty, B. L. New material of Cornwallius sookensis (Mammalia: Desmostylia) from the Columbia. Journal of Vertebrate Paleontology. 2015; 35: e979939. Yaquina Formation of Oregon. Journal of Vertebrate Paleontology. 2009; 29: 894-

Beatty, B. L. Rediscovered specimens of Cornwallius (Mammalia, Desmostylia) from Vancouver Island, British Columbia, Canada. www.PalArch.nl Vertebrate Palaeontology Series. 2006; 1-6.

Bell, M.A. and Lloyd, G.T. 2015. Strap: an R package for plotting phylogenies against stratigraphy and assessing their stratigraphic congruence. Palaeontology 58: 379389.

440 Cantino, P.D. and de Queiroz, K. 2010. International Code of Phylogenetic Nomenclature. 
443 Chiba, K., Fiorillo, A. R., Jacobs, L. L., Kimura, Y., Kobayashi, Y., Kohno, N., Nishida, Y., Michael, P. J and Tanaka, K. A new desmostylian mammal from Unalaska (USA) and the robust Sanjussen jaw from Hokkaido (Japan), with comments on feeding in derived desmostylids. Historical Biology. 2016; 28: 289-303.

Clark, J. M. A new early Miocene species of Paleoparadoxia (Mammalia: Desmostylia) from California. Journal of Vertebrate Paleontology. 1991; 11: 490-508.

Cooper, L. N., Seiffert, E. R., Clementz, M., Madar, S. I., Bajpai, S., Hussain, S. T., and Thewissen, J. G. M. Anthracobunids from the middle Eocene of India and Pakistan are stem perissodactyls. PloS one. 2014; 9: e109232.

de Queiroz, K. and Gauthier, J. Phylogenetic taxonomy. Annual review of Ecology and Systematics. 1992; 23: 449-480.

de Queiroz, K. and Gauthier, J. Phylogeny as a central principle in taxonomy: phylogenetic definitions of taxon names. Systematic Biology. 1990; 39: 307-322.

de Queiroz, K. and Gauthier, J. Toward a phylogenetic system of biological nomenclature. Tree. 1994; 9. 27-31. (Proboscidea, Mammalia) from the Eocene of Algeria: new perspectives on the ancestral morphotype of the genus. Palaeontology. 2006; 49: 421-434.

461 Domning, D. P. (1996) Bibliography and Index of the Sirenia and Desmostylia. Smithsonian Contributions to Paleobiology. 1996; 80: 1-611. 
463 Domning, D. P. (2002) The terrestrial posture of desmostylians. In: Cenozoic Mammals of Land

464

465

466

467

468

469

470

471

472

473

474

475

476

477

478

479

480

481

482

483

484 and Sea: Tributes to the Career of Clayton E. Ray, R. J. Emry, ed. Smithson. Contr. Paleobiology. 2000; 93: 99-111.

Domning, D. P. and Barnes, L. G. A new name for the 'Stanford Skeleton' of Paleoparadoxia (Mammalia, Desmostylia). Journal of Vertebrate Paleontology. 2007; 27: 748-751.

Domning, D. P., Ray C. E., and McKenna M. C. Two New Oligocene Desmostylians and a Discussion of Tethytherian Systematics. Smithsonian Contributions to Paleobiology. 1986; 59: 1-56.

Gradstein, F. M., Ogg, J. M., and Schmitz, M. A Geologic Time Scale. Elsevier, Boston, USA. 2012.

Gheerbrant, E., Filippo, A., and Schmitt, A. (2016) Convergence of Afrotherian and Laurasiatherian Ungulate-like Mammals: First Morphological Evidence from the Paleocene of Morocco. PloS one. 2016; 11: e0157556.

Gingerich, P. D. Aquatic adaptation and swimming mode inferred from skeletal proportions in the Miocene desmostylian Desmostylus. Journal of Mammalian Evolution. 2005; 12 : 183-194.

Holroyd, P. A., Simons, E. L., Bown, T. M., Polly, P. A., and Kraus, M. J. New records of terrestrial mammals from the upper Eocene Qasr el Sagha Formation, Fayum Depression, Egypt. Palaeovertebrata. 1996; 25: 175-192.

Ijiri, S. and Kamei, T. On the skulls of Desmostylus mirabilis Nagao from South Sakhalin and of Paleoparadoxia tabatai (Tokunaga) from Gifu Prefecture, Japan. Earth Science. $1961 ; 53: 1-27$. 
485 Inuzuka, N. The skeleton of Desmostylus mirabilis from South Sakhalin 1. Atlas and thoracic vertebrae. Earth Science. 1980; 34: 205-214.

Inuzuka, N. The skeleton of Desmostylus mirabilis from South Sakhalin 2. Lumbar vertebrae, sacrum and coccygeal vertebrae. Earth Science. 1980; 34: 247-257.

Inuzuka, N. (1981a) The skeleton of Desmostylus mirabilis from South Sakhalin 3. Ribs, scapula and os coxae. Earth Science. 1980; 35: 1-18.

Inuzuka, N. The skeleton of Desmostylus mirabilis from South Sakhalin 4. Metacarpus. Earth Science. 1981; 35: 240-244.

493

494

$$
\text { Science. 1982; 36: 117-127. }
$$

Inuzuka, N. (1988) The skeleton of Desmostylus from Utanobori, Hokkaido, 1. Cranium. Bulletin of the Geological Survey of Japan. 1988; 39: 139-190.

Inuzuka, N. The skeleton of Desmostylus from Utanobori, Hokkaido, Japan, 2. Postcranial skeleton, Bulletin of the Geological Survey of Japan. 2009; 60: 257-379.

Inuzuka, N. Aquatic adaptations in desmostylians. Historical Biology. 2000; 14: 97-113.

Inuzuka, N. Primitive Late Oligocene desmostylians from Japan and Phylogeny of the Desmostylia. Bulletin of the Ashoro Museum of Paleontology. 2000; 1: 91-124.

Inuzuka, N. Skeletal Restoration of the Desmostylians: Herpetiform Mammals. Memoirs of the Faculty of Science, Kyoto University. Series of biology. 1984; 9: 157-253.

Inuzuka, N. The postcranial skeleton and adaptation of Ashoroa laticosta (Mammalia: Desmostylia). Bulletin of the Ashoro Museum of Paleontology. 2011; 6: 3-57.

Inuzuka, N. The Stanford Skeleton of Paleoparadoxia (Mammalia: Desmostylia). Bulletin of Ashoro Museum of Paleontology. 2000; 3, 3-110.

PeerJ reviewing PDF | (2018:12:33598:1:1:NEW 3 Jul 2019) 
508 Jacobs, L. L., Fiorillo, A., Gangloff, R., and Pasch, A. Desmostylian remains from Unalaska 509 Island, Aleutian Chain, Alaska. In Beard, C., and Luo, Zhe-Xi ed., Mammalian

510 Paleontology on a Global Stage: Papers in Honor of Mary R. Dawson. Bulletin of the 511 Carnegie Museum of Natural History. 2007; 39: 189-202.

512 Jacobs, L. L., Fiorillo, A.R., Nishida, Y., and Fitzgerald, E. M. G. Mid-Cenozoic marine

513

514

515

516

517

518

519

520

521

522 523

524

525

526

527

528

529

530 mammals from Alaska. Papers on Geology, Vertebrate Paleontology, and Biostratigraphy in Honor of Michael O. Woodburne. Museum of Northern Arizona Bulletin. 2009; 64: 171-184.

Kohno, N. A centenary of studies on the holotype (NSM-PV 5600) of Desmostylus japonicus Tokunaga and Iwasaki, 1914. Bulletin of Ashoro Museum of Paleontology. 2000; 1: 137-151.

Linnaeus, C. 1758. Systema naturae per regna tria naturae, secundum classes, ordines, genera, species, cum characteribus, differentiis, synonymis, locis. Ed. 10, Tomus 1. L. Salvii, Stockholm, Sweden, 823p.

Maddison, W.P., and Maddison, D.R. (2011). Mesquite: a modular system for evolutionary analysis. Version 2.75. http://www.mesquiteproject.org.

Matsui, K. (2017). How can we reliably identify a taxon based on humeral morphology? Comparative morphology of desmostylian humeri. PeerJ, 5, e4011.

Matsui, K., Kimura, Y., Nagata, M., Inose, H., Ikeda, K., Beatty, B. L., Obayashi, H., Hirata, T., Otoh, S., Shinmura, T., Agematsu, S., and Sashida, K. (2018). A long-forgotten 'dinosaur'bone from a museum cabinet, uncovered to be a Japan's iconic extinct mammal, Paleoparadoxia (Desmostylia, Mammalia). Royal Society open science, $5(7), 172441$.

PeerJ reviewing PDF | (2018:12:33598:1:1:NEW 3 Jul 2019) 
531 Matsumoto, H. A contribution to the knowledge of Moeritherium. Bulletin of the American

532

533

534

535

536

537

538

539

540

541

542

543

544

545

546

547

548

549

550

551
Museum of Natural History. 1923; 48: 97-139.

Osborn, H. F. Ten years' progress in the mammalian palaeontology of North America. American Geologist. 1905; 36: 199-229.

Panofsky, A. I. Stanford Paleoparadoxia fossil skeleton mounting. Stanford Linear Accelerator Center, Stanford, California, SLAC-PUB-7829:vi + 143 pp. 1998.

Pilgrim, G.E., 1940. Middle Eocene Mammals from North-west India. In Proceedings of the Zoological Society of London (Vol. 110, No. 1-2, pp. 127-152). Oxford, UK: Blackwell Publishing Ltd.

Pronina, I. G. 1957. A new desmostylid, Kronokotherium brevimaxillare gen. nov., sp. nov., from Miocene deposits of Kamchatka. Doklady Akademii nauk SSSR, NS 117: 310$312,1 \mathrm{pl}$.

R Core Team. R: A language and environment for statistical computing. R Foundation for Statistical Computing, Vienna, Austria. URL https://www.R-project.org/. 2017.

Ray, C. E., Domning, D. P., and McKenna, M. C. A new specimen of Behemotops proteus (Order Desmostylia) from the marine Oligocene of Washington. In A. Berta, and T. A. Deméré ed., Proceedings of the San Diego Society of Natural History. 1994; 29: 205-222.

Reinhart, R. H. A review of the Sirenia and Desmostylia. University of California Publications in Geological Sciences. 1959; 36: 1-146.

Repenning, C. A. Drawing of Paleoparadoxia skeleton. Geotimes. 1965; 9: 1-3. 
552 Rose, K. D., Holbrook, L. T., Rana, R. S., Kumar, K., Jones, K. E., Ahrens, H. E., Missiaen, P.,

553

554

555

556

557

558

559

560

561

562

563

564
Sahni, A., and Smith, T. (2014). Early Eocene fossils suggest that the mammalian order Perissodactyla originated in India. Nature communications, 5, 5570.

Santos, G.-P., J. F. Parham and B. L. Beatty. New data on the ontogeny and senescence of Desmostylus (Desmostylia, Mammalia). Journal of Vertebrate Paleontology. 2016; e1078344. DOI: 10.1080/02724634.2016.1078344

Shikama, T. Postcranial skeletons of Japanese Desmostylia. Palaeontological Society of Japan Special Paper. 1966; 12: 1-202.

Swofford DL. PAUP*. Phylogenetic Analysis Using Parsimony (*and Other Methods). Version 4. Sinauer Associates, Sunderland, Massachusetts; 2002.

Yoshiwara, Y. and C. Iwasaki (1902) Notes on a new fossil mammal. Journal of the College of Science, Imperial University of Tokyo. 1902; 16: 1-13. 
Figure 1 (on next page)

Summary of hypotheses on phylogenetic affinities of Desmostylia within Mammalia.

A: Perissodactyla hypothesis, B: Afrotheria hypothesis, C: Paenungulatamorpha hypothesis. 

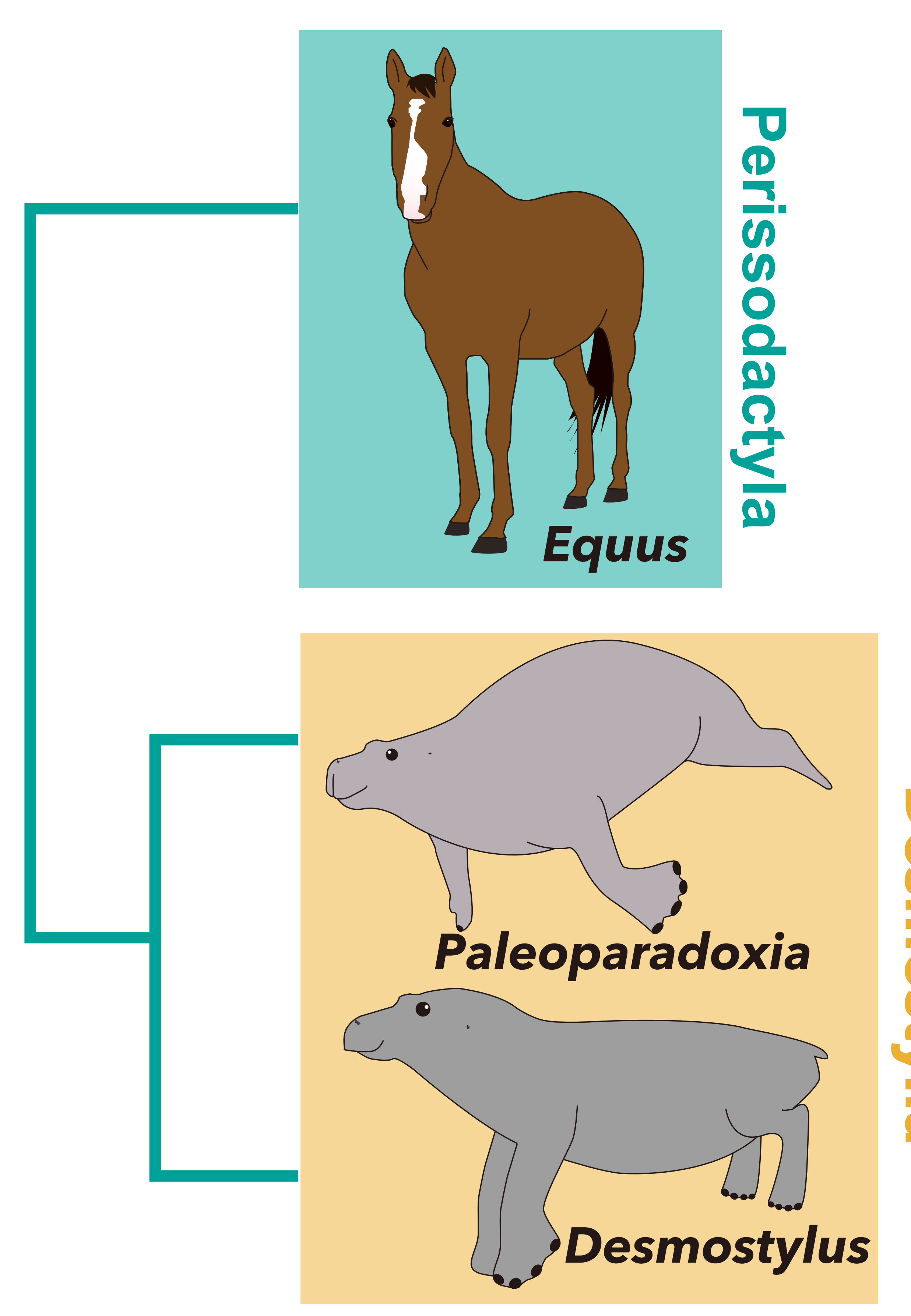

A. Perissodactyla hypothesis

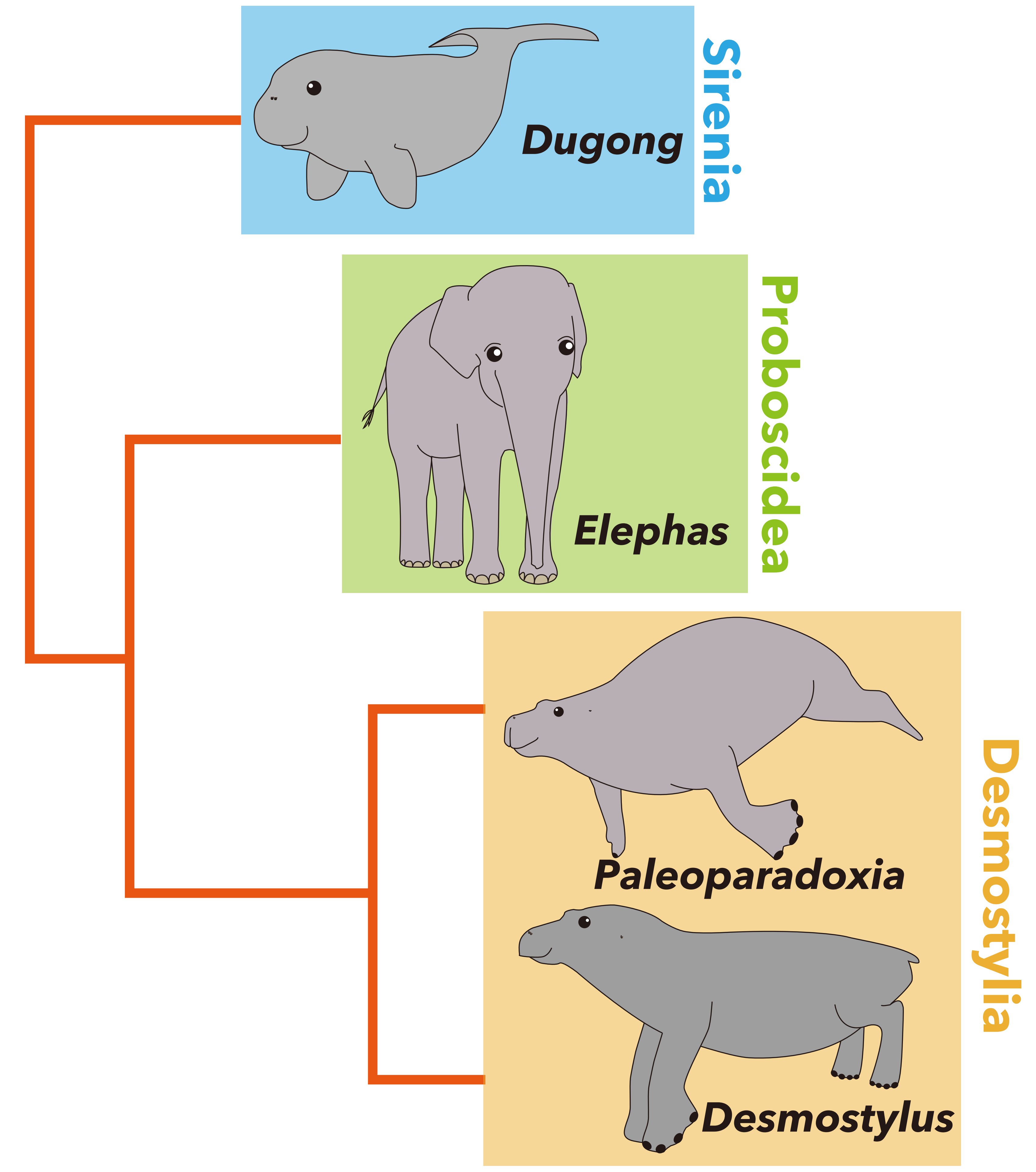

BemAfrotheriam hypothesis
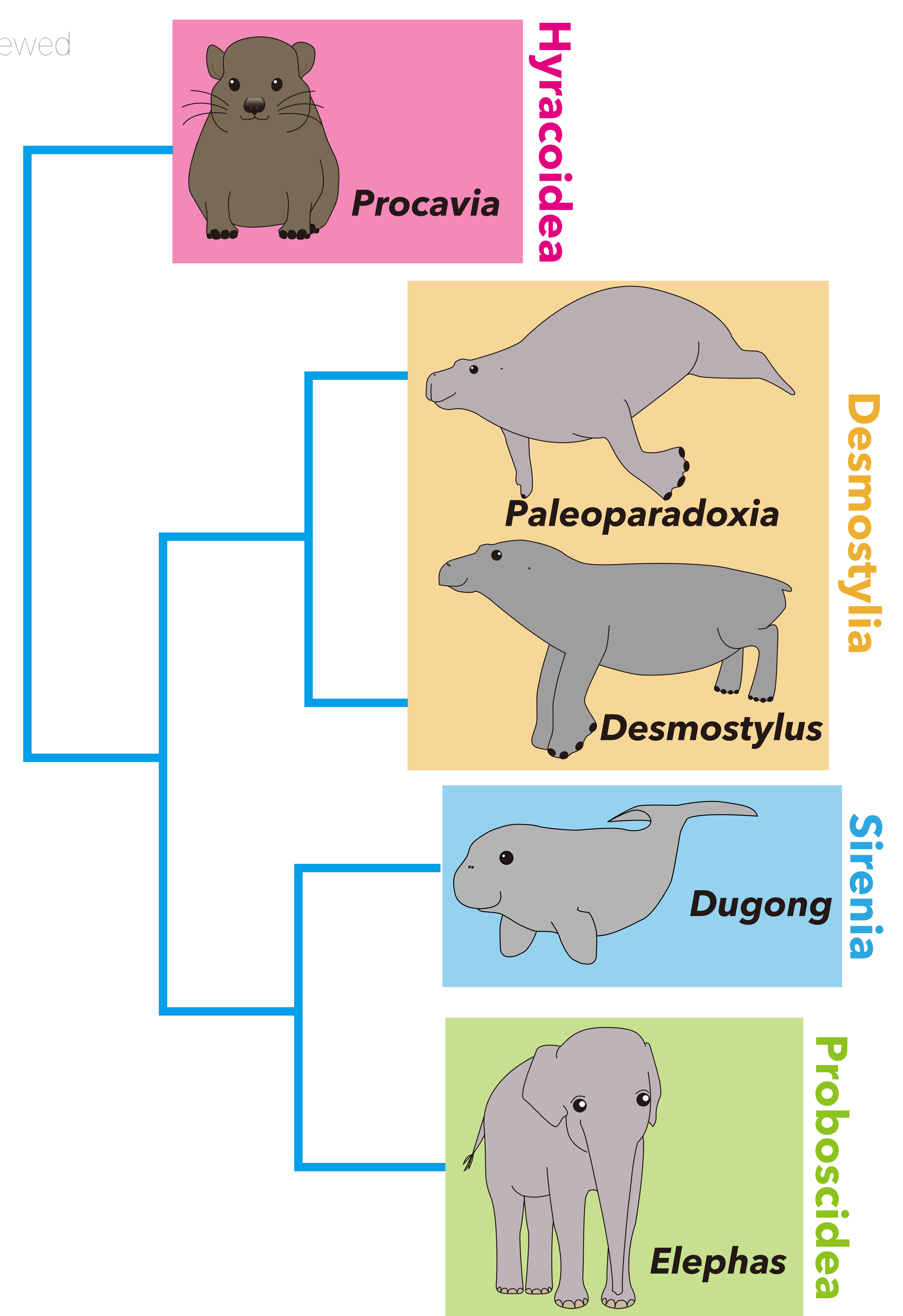

C. Paenungulatomorpha hypothesis 


\section{Figure 2 (on next page)}

Previously-proposed hypotheses on the phylogenetic interrelationship of Desmostylia.

A: the topology of Domning et al. (1986), B: the topology of Clark (1991), C: the topology of Inuzuka (2005), D: the topology of Beatty (2009), E: the topology of Barnes (2013), F: the topology of Chiba et al. (2015)

Pink: Behemotopsinae, Orange: Paleoparadoxiidae, Green: Paleoparadoxiinae, Yellow: Desmostylidae. 
Figure 3 (on next page)

Distribution of morphological characters by the region used in the new matrix assembled in the present study.

The skeleton is Neoparadoxia repenningi modified from Panofsky (1998). Purple: teeth, Orange: skull, Yellow: mandible, Blue: forelimb, Pink: trunk, Green: hindlimb. 
28

Teeth 35

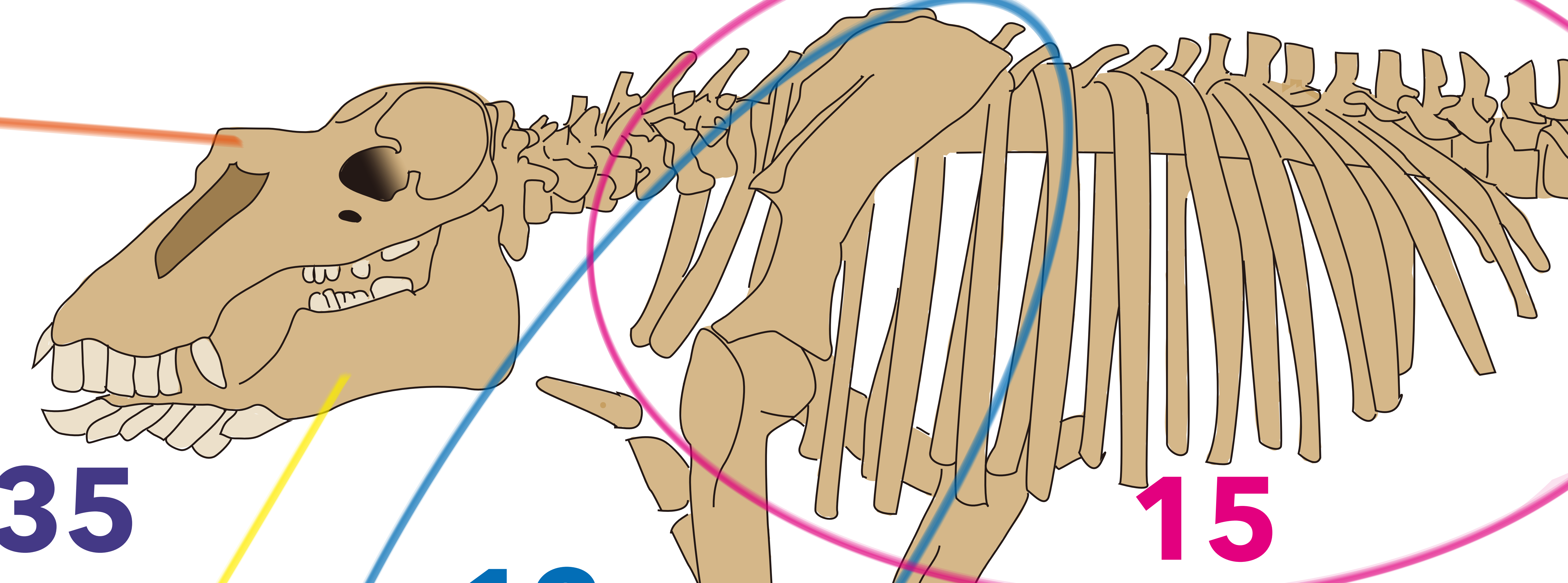

9

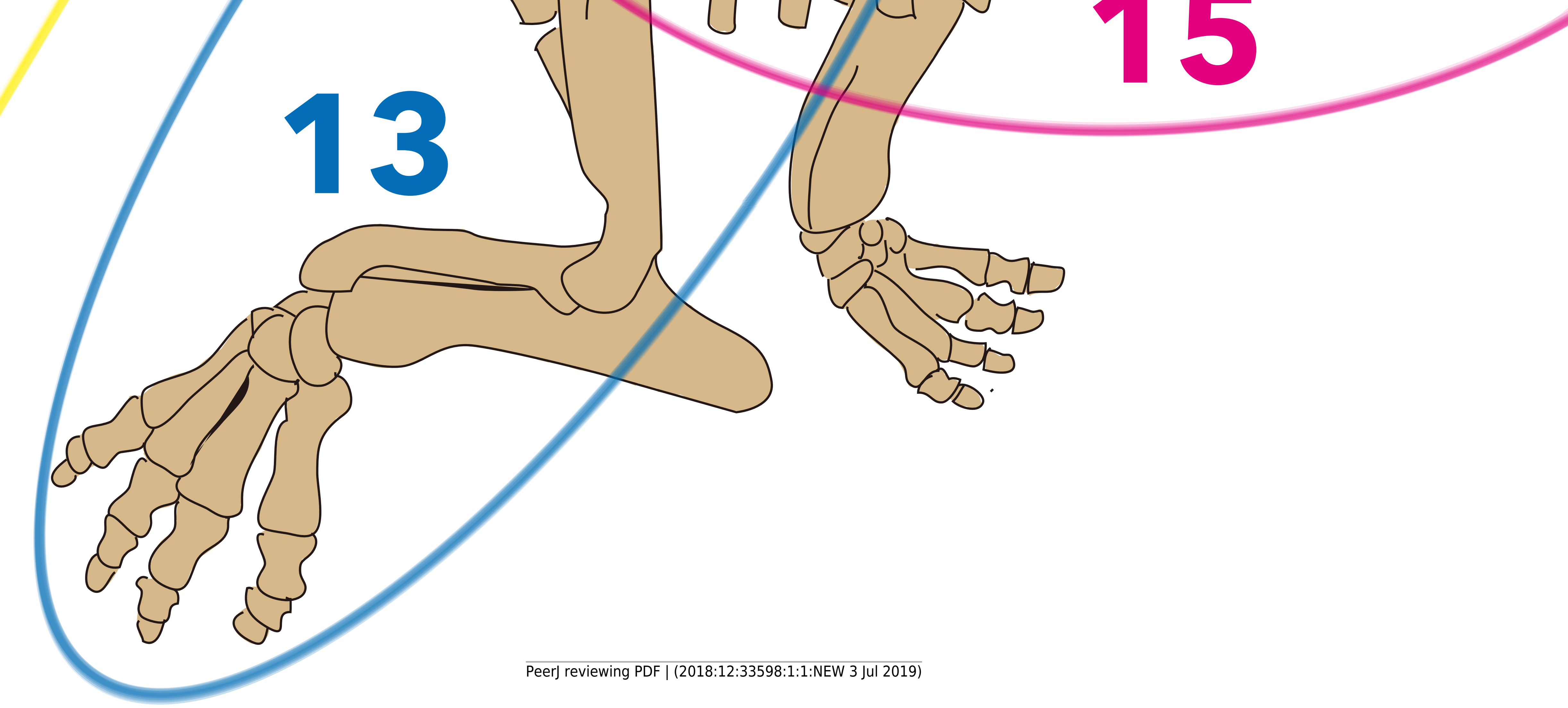

8

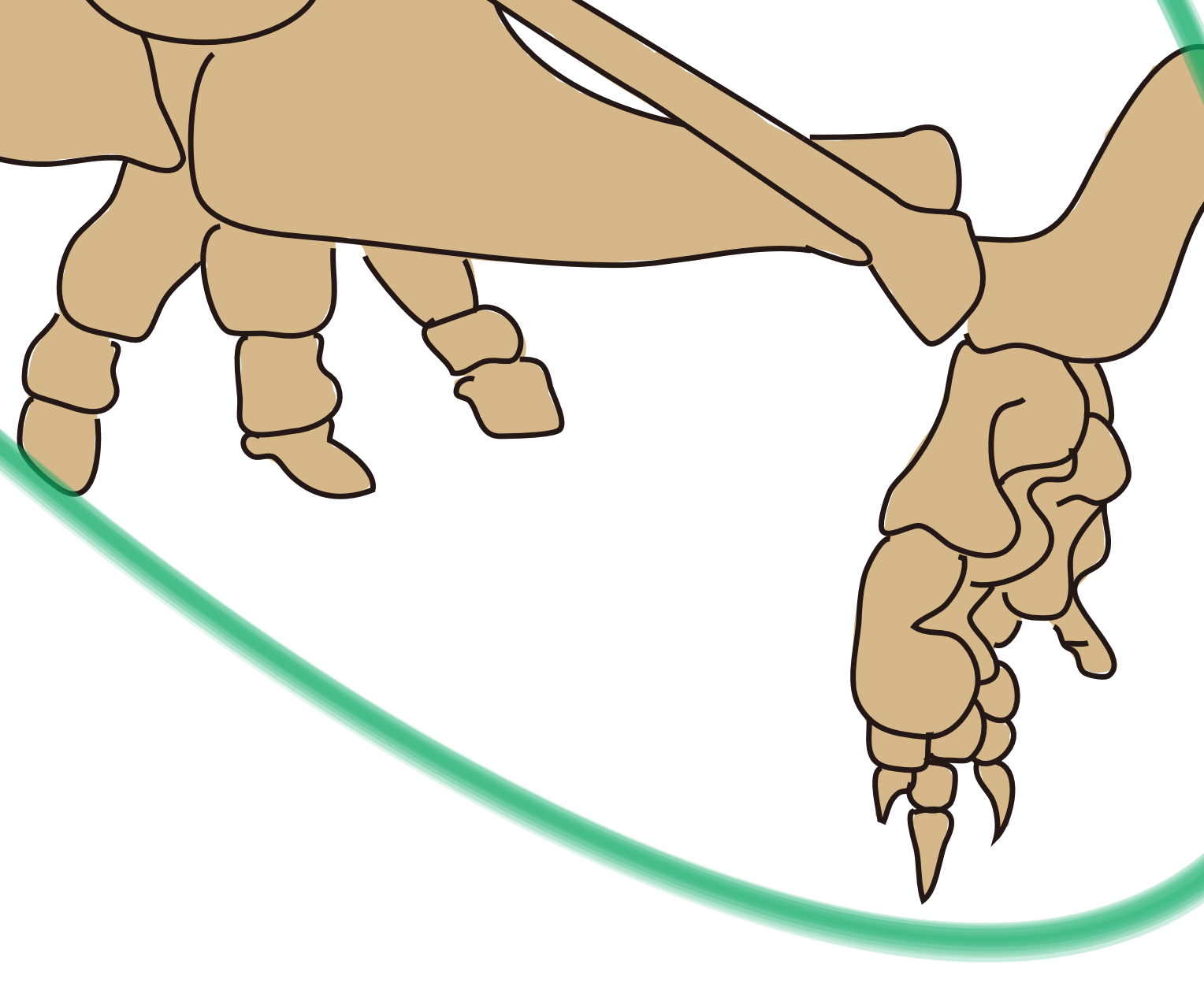


Figure 4 (on next page)

Time-calibrated strict consensus tree resulting from the present analyses.

The number written in red below each node represents the bootstrap value (in \%). The numbers written in blue indicate characters and character states representing synapomorphies for each node.

Black bar: geological range, Green: Desmostylia, Blue: Desmostyloidea, Orange: Paleoparadoxiidae, Yellow: Desmostylidae. $\mathrm{L}=205, \mathrm{Cl}=0.668, \mathrm{RI}=0.682, \mathrm{RC}=0.456, \mathrm{HI}=0.332$, G-fit $=-78.950$. 


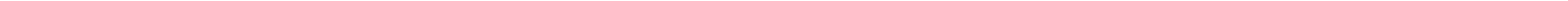

